\title{
ASBÂB AL-WURÛD AL-HADÎTS DALAM MEMAHAMI HADITS AHKAM
}

\author{
Zainul Arifin \\ Fakultas Psikologi UIN Maulana Malik Ibrahim Malang \\ Email: gmail.com.zainularifin65@gmail.com
}

\begin{abstract}
Abstrak
This research purposes to describe the urgence and implementation of asbâb al-wurûd al-haditsin understanding of the text of the prophetic tradition. The urgence of asbâb al-wurûd al-hadîs seems in the understanding of the tradition with many component; that are communicator, audince, context (place and time). While the implementation of asbâb al-wurûd al-haditsshows in a sample of the tradition about aqiqah, whith background of it. Base on that understanding, we have the polarization meaning of this tradition in its context for the future. The pointers of this development meaning of hadits with asbâb al-wurûd al-hadîts is moral ideal of this traditions as thanksgiving to God for His blessing and the salvation of the baby.

Karya ini bertujuan untuk mendeskripsikan tentang kerangka pengembangan pemahaman terhadap makna teks suatu hadis dari sisi urgensi dan ilmplementasi asbâb al-wurûd al-hadîs. Urgensi asbâb al-wurûd al-hadîts nampak pada pemahaman yang menyertakan empat komponen al-bu'du almukhatibi (komunikator), al-bu'du al-mukhatabi(audien), al-bu'du al-zamani (waktu) dan al-bu'du al-makani (tempat). Implementasi asbâb al-wurûd al-hadis nampak pada sampel hadis tentang aqiqah difahami melalui asbâb al-wurûd yang menyertai hadis tersebut, sehingga diperoleh pemahaman terhadap makna hadis secara beragam, sesuai dengan konteks dan upaya kontekstualisasi makna hadis di masa yang akan datang. Oleh karenanya, jumlah atau jenis hewan yang dijadikan aqiqah, bukan persoalan yang harus dipahami secara kaku. Poin penting atau semangat yang ditekankan dalam hadis-hadis tersebut adalah ideal moral yang terkandung di dalamnya, yaitu ungkapan rasa syukur atas keselamatan bayi yang dianugerahkan oleh Allah swt.
\end{abstract}

Kata kunci : Asbâb al-wurud, teks hadis, urgensi, dan implementasi

Hadis yang dalam tataran historis merupakan manifestasi dari sunnah nabi, ${ }^{1}$ baik berupa aspek verbal (qaulan) maupun aspek non verbal (fi'lan au taqrîron) secara tradisional difahami dan ditangkap oleh masyarakat sebagai sebuah teks yang sarat dengan pesan norma agama (baca: Islam). Pembacaan terhadap teks-teks hadis ini bukan berarti tanpa alasan. Hal ini, memang berdasar kerangka teori tertentu (misalnya: teori atribusi dalam perspektif psikologi), bisa dimaklumi, karena hampir apa saja perilaku

Muhammad Ajjaj al-Khatib, As-Sunnah Qabla al-Tadwin (Bairut: Dar al-Fikri, 1993), h. 2122 . seseorang baik itu verbalistik maupun non verbal selalu lekat dengan atribut yang dimiliki oleh seseorang tersebut.

Muhammad, dalam konteks historisnya telah memiliki beberapa atribut yang menempel pada dirinya. kendatipun sebagai manusia biasa di satu sisi memiliki fungsi riasah (atribut negarawan), namun di sisi lain adalah person yang sangat lekat dengan fungsi riayah (atribut kenabian, tokoh agamawan). Dengan demikian sebagai nabi dengan atribut tokoh agama, maka apapun perilakunya mencerminkan nilai agama dan ditangkap oleh audien para pengikutnya 
sebagai pesan yang sarat dengan norma agama. Sampai hari ini, pembacaan umat terhadap teks hadis masih dominan nilai agama dibanding dengan nilai universal lain yang mungkin terkandung dari teks suatu hadis tersebut. ${ }^{2}$

Kesadaran baru, akan urgensi pengembangan metodologi dan pendekatan pemahaman terhadap teks hadis tersebut telah dilakukan dengan indikasi munculnya metodologi studi Islam. Dengan harapan pembacaan teradap teks hadis tertentu tidak lagi dihampiri dengan pendekatan klasik sebagaimana tradisi selama ini dilakukan, baik itu dengan pendekatan filologis (uslub lughoh, qawaidul lughoh, atau balaghoh), maupun dengan pendekatan takhrij al-hadis dan naqdu al-hadis (baik jalur matan maupun sanadnya). ${ }^{3}$

Tanpa mengesampingkan pendekatan klasik dalam upaya pembacaan hadis nabi, maka hazanahklasik yang memiliki semangat sholihun likulli zaman wa al-makan adalah disiplin ilmu asbâb al-wurûd. Karena dengan implementasi asbâb al-wurûd tersebut dalam praktek pembacaan sebuah hadis; maka hadis tidak saja difahami secara tekstual (lafdziyah), akan tetapi hadis difahami dalam konteks dimana hadis itu diproduk oleh Nabi disertai latar sosio hitoris yang menyertai (asbâb al-wurûd-nya), yang selanjutnya berdasar pemahaman kontekstual tersebut dilakukan upaya kontekstualisasi teks dan makna hadis ke dalam situasi dan kondisi sekarang yang secara interval waktu maupun latar sosio historisnya jauh berbeda dengan latar sosiohostoris peristiwa di masa kontemporer sekarang ini. ${ }^{4}$

2 Adnan Muhammad Amamah, At-Tajdidu fi al-Fikri al-Islami (Saudi Arabia: Dar Ibnu Hazm, 1424 H.) h. 189.

3 Subhi As-Shalih, Ulumal-Hadits wa Mustalahuhu, (Bairut: Dar al-Ilm Al-Malayin, 1977), h. 45 dan Mahmud at-Thahhan, Taisir Musthalah al-Hadis, (Beirut : Dar alQuran al-Karim, 1979), h. 16.

4 Yunahar Ilyas dan M. Mas'udi (ed.), Pengembangan Pemikiran terhadap Hadis, (Yogyakarta: LPPI UMY, 1996), h. 100. Lihat pula Badri Khaeruman, Otentisitas Hadis: Studi Kritis atas Kajian Hadis Kontemporer, (Bandung: Rosda, 2004), h. 44. Dan Amin Abdullah, Mempertautkan Ulum Al-Diin, Al-Fikr Al-Islamiy dan Dirasat Islamiyyah:
Berdasar kerangka pengembangan pemahaman terhadap makna teks suatu hadis inilah diskursus tentang urgensi dan ilmplementasi pengembangan pemahaman makna teks hadis ini menjadi menarik untuk dikajia dan disajikan dalam karya ini.

\section{Asbâb al-wurûd: Penelusuran Akar Makna dalam Diskursus Mustholah al-Hadis}

Secara etimologis, asbâb al-wurûd merupakan susunan idafah dari kata asbâb dan wurûd. Kata asbâb adalah bentuk jamak taksir (irregular plural nouns) dari kata sabab, yang berarti "al-habl" berati tali atau penghubung, yaitu segala sesuatu yang dapat menghubungkan kepada sesuatu yang lain, atau penyebab terjadinya sesuatu. Ada juga yang mendifinisikan dengan : "suatu jalan menuju terbentuknya suatu hukum tanpa ada pengaruh apapun dalam hukum itu". ${ }^{5}$

Sedangkan kata wurûd merupakan bentuk isim masdar (kata benda abstrak yang dibentuk dari kata kerja). Dalam tashrifiyyah kata tersebut berasal dari fi'il madhi (kata kerja lampau)-nya warada, fi'il mudori'-nya yaridu, lalu dibentuk menjadi isim masdar, wurûdan, yang berarti datang atau tiba atau sampai atau muncul, dan mengalir seperti "air yang memancar atau air yang mengalir "6

Secara terminologis (ishthilahan), terdapat beberapa definisi dalam diskursus ilmu hadis asbâb al-wurûd diberi makna sebagai: "Metode untuk menentukan maksud sebuah hadis yang bersifat umum, khusus, mutlaq, muqayyad dan juga menentukan ada atau tidaknya naskh (pembatalan) dalam sebuah hadis".7

Imam as-Suyuthi mendefinisikan asbâb al-wurûd dengan, "Sesuatu yang menjadi thoriq (jalan atau metode) yang menentukan

$\overline{\text { Sumbangan Keilmuan Islam untuk Peradaban Global }}$ dalam (Online) (http:// aminabd.wordpress. com/ category/ tulisan-2008/Diakses 12 Maret 2011).

Ibn Manzur, Lisan Al-Arab, (Beirut: Dar al-Fikr, 1990), Jilid I , h. 44.

6 Ahmad Warson, Kamus Al-Munawwir ArabIndonesia, (Yogyakarta: Unit Pengadaan Buku-buku Ilmiah Keagamaan, 1984), h. 1655.

7 Ahmad Umar Hasyim, Qowa'id Ushul alHadis, (Beirut: Dar al-Fikr, tth.), h. 260. 
maksud suatu hadis yang bersifat umum atau khusus, mutlaq atau muqayyad, dan untuk menentukan ada atau tidaknya naskh (penghapusan permberlakuan) dalam hadis tertentu, dan lain sebagainya". ${ }^{8}$

Said Aqil Husein al-Munawwar mengomentari defenisi as-Suyuthi ini dengan mengatakan, jika defenisi itu dicermati, tampaknya lebih mengacu pada fungsi asbâb al-wurûd yang diantaranya mencakup penentuan ada tidaknya naskh-mansukh dan lain-lain. Jadi, menurut Aqil, kurang tepat jika defenisi itu diberikan untuk cabang ilmu hadist asbâb al-wurûd. ${ }^{9}$ Aqil lebih setuju dengan defenisi yang diberikan oleh Hasbi Ash-Shiddiqy, sebagai : "Ilmu yang dengannya diketahui sebab-sebab dan zaman (konteks) yang turut dalam hadirnya suatu hadis". ${ }^{10}$

Ada juga ulama yang mendefenisikan asbâb al-wurûd mirip dengan defenisi asbâb al-nuzul dalam studi ilmu-ilmu Al-Qur'an (ulumul Qur'an). Sehingga definisi tersebut menjadi, "Sesuatu (dapat berupa peristiwa atau pertanyaan) yang terjadi pada waktu sebuah hadis disampaikan oleh Nabi saw" ${ }^{11}$

Dengan demikian dapat dipahami bahwa asbâb al-wurûd merupakan latar belakang (background), sebab-sebab terjadinya atau konteks historisitas sebuah peristiwa, baik berupa peristiwa-peristiwa, pertanyaanpertanyaan atau lainnya yang terjadi pada saat hadis itu di sampaikan oleh Nabi saw. Kendatipun tidak semua hadis mempunyai asbâb al-wurûd. Demikian juga, ada hadis yang mempunyai asbâb al-wurûd secara khusus, tegas dan jelas, namun sebagian yang lain tidak.

\footnotetext{
Jalaluddin Abrurrahman as-Suyuthi, alLuma' fi Asbâbi Wurûd al-Hadis, (Beirut: Dar alFikr,tth.), h.11.

9 Said Aqil Husein al-Munawwar, Metode Pemahaman Hadis: Pendekatan Historis, Sosiologis dan Antropologis, Metafora, (Yogyakarta: Pustaka Pelajar), 1998), h. 32.

10 TM. Hasbi Ash-Shidiqqy, Sejarah dan Pengantar Ilmu Hadis, (Semarang: PT. Pustaka Rizki Putra, 1997), Cet. I, h. 142.

11 Ahmad Umar Hasyim, Qowa'id Ushul alHadis, (Beirut: Dar al-Fikr, tth), h. 260.
}

\section{Urgensi Asbâb al-wurûd}

Asbâb al-wurûd mempunyai peranan yang sangat penting dalam rangka memahami suatu hadis. Sebab biasanya hadis yang disampaikan oleh Nabi bersifat kasuistik, kultural, bahkan temporal. Oleh karenanya, memperhatikan konteks historisitas munculnya hadis sangat penting, karena paling tidak akan menghindarkan kesalahpahaman dalam menangkap maksud suatu hadis. Sehingga tidak terjebak pada teksnya saja, sementara konteksnya diabaikan atau dikesampingkan sama sekali. Pemahaman hadis yang mengabaikan peranan asbâb al-wurûd akan cenderung bersfat rigid, literalis, skriptualis, bahkan kadang kurang akomodatif terhadap perkembangan zaman.

Urgensi asbâb al-wurûd ini, oleh Khaled Abou El-Fadl, guru besar Figh dan Ushul al-Figh pada University of California at Los Angeles (UCLA) dalam beberapa bukunya secara teoritis disinggungbahwapembahasan tentang pentingnya memperhatikan dialektika yang terjadi antara otoritas teks, konteks, otoritas pengarang - dalam pembicaraan kita adalah Nabi sendiri- dan konteks pembaca teks. Dia juga menekankan pentingnya membedakan fungsi dan status sebuah hadis Nabi dalam kaitannya dengan latar belakang hadirnya hadis tersebut. Pembedaan itu berimplikasi pada nilai imperatif masing-masing hadis dalam kaitannya dengan fungsi hadis sebagai salah satu sumber hukum dalam hukum Islam. Hal ini karena terkait erat dengan konteks dan otoritas Nabi saat menyampaikan suatu hadis.

Urgensi asbâb al-wurûd tersebut oleh Khaled Abou El-Fadl dalam bukunya And God Knows The Soldiers, The Authoritative and Authoritarian in Islamic Discourse, dipaparkan bahwa: "In the discourse on the prophet's legacy (sirah), not all of the pophet's acts are of equal imperative value. Rather, their value is dependent upon their categorization. Some of the sunnah is tasyri'iyyah (intended by the prophet to be 
legislative) and some constitutes af'al jibiliyyah (personal behavior not intended by the prophet to be legislative)". ${ }^{12}$

Lebih dari yang disebutkan oleh Khaled Abou El-Fadl, mempelajari hadis dengan memperhatikan sebab-sebab khususnya dan illat (alasan hukum) yang melatarbelakangi hadirnya sebuah hadis dibutuhkan karena, ada hadis yang sepintas tampak umum, tetapi setelah dikaji secara seksama, ternyata ada illat hukum yang menyertainya.

Maka, jika illat hukum itu hilang atau berubah, harusnya diikuti perubahan status hukum atas masalah tersebut. Dalam kajian Ushul al-Figh (metodologi atau juga filsafat hukum Islam) dikenal kaidah (rumusan teoritis) yang berbunyi : "Status hukum suatu masalah berubah sesuai dengan perubahan alasan penetapan hukumnya."13

Hubungannya dengan kaidah di atas, lebih lanjut disebutkan bahwa, dalam upaya memahamihadisharuslahdiketahuivariabelvariabel yang melingkupinya, bahkan dimana dan untuk tujuan apa hadis tersebut dimunculkan Nabi. Lantaran berbagai hadis itu membicarakan hal-hal yang berkenaan dengan banyak masalah, ada yang bersifat lokal, partikular, temporal, ada juga yang berfungsi sebagai pemerinci atau penjelas bagi ayat-ayat al-Qur'an tertentu. Ada juga yang menjelaskan banyak hal yang tidak terdapat dalam al-Qur'an. Bahkan, seperti yang telah diingatkan oleh Khaled Abou ElFadl, ada hadis yang bermuatan tasyri'iyyah (menjadi ketetapan atau sumber penetapan hukum) dan ada juga yang af'al al-jibiliyyah (perilaku atau tatakrama kehidupan Nabi yang tidak menjadi ketetapan hukum atau sumber hukum).

Oleh karena itu pemahaman tentang asbâb al-wurûd al-hadis perlu diperhatikan beberapa komponen yang berkaitan dengan latar

\footnotetext{
Khaled Abou El-Fadl, And God Knows The Soldiers, The Authoritative and Authoritarian in Islamic Discourse, , (Maryland : University Press of America, 1997), h. 50-51.

${ }_{13}$ Lebih lanjut, lihat keterangan tentang Kaedah Ushul Fiqh tersebut pada Muhammad Ibn Idris as-Syafi'i, Ar-Risalah, (Beirut: Dar al-Fikr, tth) h. 213.
}

belakang hadis atau bagaimana sehingga Nabi saw bersabda dan bersikap. Adapun komponen tersebut dapat dipetakan sebagai berikut: a) al-bu'du al-mukhatibi (faktor yang muncul dari pribadi Nabi saw. sebagai pembicara), b) al-bu'du al-mukhatabi (faktor yang berkaitan dengan kondisi orang yang diajak berbicara), c) al-bu'du az-zamani (aspek yang berkaitan dengan waktu atau masa di mana Nabi menyampaikan sabdanya), dan d) al-bu'du al-makani (aspek yang berkaitan dengan tempat atau kondisi geografis di mana Nabi menyampaikan hadis).

Secara rinci asbâb al-wurûd dalam konteks pemahaman hadis memiliki fungsi untuk : a) menentukan adanya takhsis hadis yang masih bersifat umum, b) membatasi pengertian hadis yang masih mutlak, c) memperinci (tafsil) hadis yang masih bersifat global, d) menentukan ada atau tidaknya naskh dan mansukh dalam suatu hadis, e) menjelaskan 'illat atau sebab-sebab ditetapkannya suatu hukum, dan f) menjelaskan maksud hadis yang masih musykil (sulit dipahami).

Selain itu, asbâb al-wurûd merupakan alat bantu untuk memperoleh ketepatan makna sebuah hadis, karena sebagaimana sekilas diuraikan sebelumnya bahwa sebagai seorang utusan (Rasul), beliau juga seorang kepala negara, panglima perang. Bahkan ia juga seorang manusia biasa yang memiliki keluarga sehingga ungkapan-ungkapan Nabi saw, ada yang harus dipahami secara universal maupun kasuistik, lokal, kultural dan juga temporal.

\section{Asbâb al-wurûd: Potensi Keragaman Pemahaman Hadis}

Konteks historisitas sebuah peristiwa, baik berupa peristiwa-peristiwa, pertanyaanpertanyaan atau lainnya yang terjadi, kemudian direkam dalam catatan-catatan yang pada umumnya terintegrasi dalam teksteks hadis, merupakan konteks yang dapat dipahami sebagai konteks yang melingkupi secara mikro (baca: asbâb al-wurûd mikro). Sementara informasi-informasi atau hadis 
yang tidak memiliki catatan-catatan yang merangkum dalam konteks apa dan bagaimana sebuah peristiwa dimana hadisitu muncul dapat dilacak dan dipahami dengan mempertimbangkan konteks historisitas yang lebih luas yaitu setting sosial dan cara pandang masyarakat Arab secara umum pada masa itu, merupakan konteks makro (baca: asbâb al-wurûd makro).

Nah, dalam upaya memahami pesanpesan di balik suatu hadis yang tidak memilkiasbâbal-wurûd secara khusus, sebagai alternatifnya dapat menggunakan beberapa pendekatan alternatif yang secara sederhana dikemukakan pada poin berikutnya. Dengan demikian, mengetahui asbâb al-wurûd bukan merupakan sebuah tujuan melainkan sebagai pisau analisis atau media untuk memperoleh ketepatan makna dalam memahami pesan moral suatu hadis.

Imam as-Suyuthi menjelaskan, bahwa asbâb al-wurûd dapat dikategorikan menjadi tiga macam, yaitu: a) Mengetahui asbâb alwurûd yang sebabnya dari ayat-ayat tertentu al-Qur'an, b) Dari yang berupa hadis itu sendiri, dan c) Dari keterangan yang berkaitan dengan para pendengar atau para sahabat Nabi. ${ }^{14}$

Pertama, Sebab yang berupa ayat alQur'an. Sebab ini dikarenakan oleh ayat Al-Qur'an yang turun dalam bentuk umum, namun yang dikehendaki oleh ayat tersebut adalah makna khusus. Contohnya, firman Allah: "Orang-orang beriman yang tidak mencampurkan keimanan mereka dengan kezholiman, mereka itulah yang mendapat keamanan dan merekalah yang diberi petunjuk." (Qs. Al-An'am:82)

Saat ayat ini turun, sebagian sahabat nabi memperselisihkan apa yang dimaksud dengan kata dhulmun (kezholiman) pada ayat tersebut.Adayangmengartikannyadenganaljaur (aniaya), ada pula yang mengartikannya dengan mujawat al-had (melanggar aturan). Agar tidak terus berselisih, mereka lalu mengadu kepada Nabi dengan mengajukan

\footnotetext{
${ }^{14}$ as-Suyuthi, Op.cit., h.11.
}

pertanyaan yang bersifat mempertanyakan. Nabi lalu menjelaskan kepada mereka bahwa yang dimaksud oleh kata tersebut adalah as-syirk (syirik atau menyekutukan Tuhan). Keterangan ini terdapat dalam hadis yang diriwayatkan Imam al-Bukhori dari Abdullah Ibn Mas'ud, sebagai berikut:

Qutaibah Ibn Said telah memberitakan kepada kami. (Qutaibah berkata) Jarir telah memberitakan kepada kami dari al A'masy dari Ibrahim dari al-Qomah dari Abdullah Ibn Mas'ud semoga Allah meridhoi-nya: Ibn Mas'ud berkata: Ketika ayat berikut turun (maksudnya, ayat AlAn'am:82 di atas): "Orang-orang beriman yang tidak mencampurkan keimanan mereka dengan kezholiman, mereka itulah yang mendapat keamanan dan merekalah yang diberi petunjuk." Para sahabat Nabi merasa berat dan berkata: "Siapa diantara kita yang tidak mencampurkan keimanannya dengan perbuatan zholim?" Lalu Nabi bersabda: "Bukan itu maksudnya. Tidakkah kalian pernah mendengar ucapan Lukman kepada puteranya bahwa: "Sesungouhnya syirik (menyekutukan Allah) sungguh merupakan kezholiman yang paling besar." Qs. Lukman:13 15

Kedua, Sebab yang berupa hadist. Asbâb al-wurûd yang tercantum dalam suatu hadis kadang tercantum dalam hadis itu sendiri. Sebagai contoh adalah hadis Nabi tentang Iman, Islam dan Ihsan yang terjemahannya sebagai berikut:

Kami diberitakan dari Musaddad, ia berkata: Kami diberitakan dari Isma'il bin Ibrahim, kami diberitakan dari Abu Hayyan al-Qayyimy dari Abu Zur'ah dari Abu Hurairah. Ia berkata: "Pada suatu hari Rasul berada bersama para sahabat, lalu seorang pria datang kepada bellau lalu bertanya: "Apakah iman itu?" Beliau menjawab, "Iman adalah kamu percaya kepada Allah dan malaikat-Nya, percaya dengan adanya pertemuan dengan-Nya, dan dengan rasulrasul-Nya, dan kamu percaya dengan adanya hari kebangkitan." Ia bertanya: "ASpakah Islam itu?" Beliau menjawab: "Islam yaitu kamu menyembah Allah dan tidak menyekutukan-

15 al-Bukhori, Kitab Shohih Bukhori, Hadist nomor 6689, hal. 2088 Dan lihat Depag, Al-Qur'an Terjemahan, Departemen Agama, 1992, h. 632. 
Nya, mendirikan sholat, menunaikan zakat yang diwajibkan, dan berpuasa pada bulan Ramadhan. Ia bertanya: "Aakah ihsan itu?" beliau menjawab,"Hendaknya kamu menyembahkan Allah seakan kamu melihat-Nya. Tapi jika kamu tidak melihatnya, sesungguh-Nya Dia melihat mu. Dia bertanya lagi: "Kapan hari kiamat itu?" Nabi menjawan, "Orang yang ditanya tidak lebih tahu dari yang bertanya. Akan tetapi aku akan beritahu kamu tanda-tandanya, (yaitu) apabila seorang budak perempuan melahirkan tuannya, apabila pengembala unta dan ternak berlombalomba dalam bangunan; dalam lima hal tidak ada yang mengetahuinya kecuali Allah." Kemudian Nabi membaca ayat al-Qur'an: "Sesungguhnya Allah, hanya pada sisi-Nya saja pengetahuan tentang hari kiamat (Qs. Luqman:34). Orang yang bertanya itu pun pergi, Nabi lalu berkata: "kembalikanlah dia," akan tetapi para sahabat tidak melihat apa-apa (mungkin maksudnya sesuatu yang ucapan Nabi itu ditujukan), maka beilau bersabda: "(orang yang bertanya) itu adalah Jibril yang datang untuk mengajarkan tentang agama kepada manusia." 16

Pada hadis di atas tampak jelas, bahwa asbâbul wurûd-nya merupakan pertanyaan seorang lelaki (Jibril) kepada Nabi Muhammad.

Dalam salah satu keterangannya, Ali Mustofa Ya'qub pernah menyampaikan, bahwa hadis di atas dijadikan landasan oleh sejumlah ulama dalam menetapkan rukun iman, rukun Islam dan defenisi ihsan. Tapi perlu saya sampaikan, bahwa matan (redaksi) hadist yang sanad (jalur transmisi)-nya diterima melalui sahabat Nabi Abu Hurairah di atas, kurang lengkap. Untuk mendapatkan gambaran matan yang lebih utuh, Ya'qub sarankan agar merujuk ke matan hadis yang sama, tapi sanad-nya berpangkal pada sahabat Nabi, Ibn Umar.

Ketiga, Asbâb al-wurûd tercantum dalam hadis yang lain. Sering pula asbâb al-wurûd suatu hadis terdapat dalam informasi hadis lain yang sanad-nya berlainan. Contohnya, 16 Nawawi, al-hadis al-Arbain, Hadis Digital, Hadis No. 1. hadis tentang keutamaan niat berhijrah yang sanadnya berlainan. Sebagaimana dipaparkan dalam hadis al-Bukhori sebagai berikut:

(Imam Bukhori berkata) Kami diberitakan oleh Qutaibah bin Said, (Qutaibah berkata) Kami diberitakan dari Abdul Wahab, ia berkata: Aku mendengar Yahya bin Said berkata: Aku diberitakan dari Muhammad bin Ibrahim bahwa ia mendengar al-Qomah al-Laysy berkata: Aku mendengar Umar bin Khattab berkata: Aku mendengar Rasulullah bersabda: Segala amal berbuatan ditentukan dengan niat. Karena itu barang siapa berhijrah karena Allah dan Rasul-Nya, maka hijrahnya ialah karena Allah dan Rasul-Nya. Dan barang siapa yang hijrah untuk memperoleh keduniaan dan wanita yang akan ia kawini, maka hijrahnya itu untuk apa yang ia inginkan." (Hadist Shohih atau otentik, dibenarkan otensisitasnya oleh Bukhori dan Imam Muslim). ${ }^{17}$

Adapun asbâb al-wurûd hadis di atas dapat ditemukan pada kitab Mu'jamul-Kabir karya Imam at-Thabrany yang bersanad tsiqoh (transmisi dapat dipercaya) dari Ibn Mas'ud.

\section{Asbâb al-wurûd al-Hadis: Perspektif Metodologis dan Pendekatan Memahaminya}

Menurut Imam As-Suyuti dalam kitabnya al-Luma' fi Asbâbi al-Wurûd al-Hadis embrio mengenai cara mengetahui asbâb al-wurûd al-hadis sebenarnya sudah ada sejak masa sahabat Nabi, hanya saja belum tersusun secara sistematis. ${ }^{18}$ Selanjutnya embrio tersebut mengalami perkembangan dan disusun dalam kitab-kitab yang lebih sistematis.

Berikut adalah beberapa kitab yang membahas asbâb a- wurûd al-hadis. 1) Asbâb al-wurûd al-Hadis karya Abu Hafs Umar bin Muhammad bin Raja al-Ukhbari (380-458 H), 2) Asbâb al-wurûd al-hadis karya Abu Hamid

17 al-Bukhori, Kitab Shohih Bukhori, Hadist nomor 6689, h. 2088.

18 Jalal al-Din as-Suyuti, Asbâb Wurûd alHadis aw al-Luma'fi Asbâbi al-Hadis, ditahqiq Yahya Isma'il Ahmad, (Beirut: Dar al-Kutub al-'Ilmiyyah, 1984), h. 11. 
bin Kaznah al-Jubary, 3) Asbâb al-wurûd alhadis kitab ini disebut juga Al-Luma' fi Asbâb al-wurûd al- Hadis Karya Imam Jalaluddin Abdurrahman As-Suyuti. Beliau membahas asbâb al-wurûd tersebut dalam kitab ini berdasar bab. Dia menyebutkan kira-kira seratus hadis. Ini merupakan kitab terakhir yang beliau tulis dari ratusan karya tulisnya. Namun ajal terlebih dahulu menjemput beliau sebelum menyelesaikan menulis kitab ini, 4) Al-Bayan wa Ta'rif fi Asbâb alwurûd al-Hadis, karya Ibrahim Muhammad bin Kamaluddin al-Hanafy ad-Dimasyqi. Dikenal dengan Ibn Hamzah (w. 1054-1120 H/1644 - 1708 M). Dalam kitab ini beliau mencantumkan sekitar 1831 hadis dengan tebal tiga jilid. Kitab ini disusun secara alfabetis berdasarkan potongan hadis yang kemudian dijelaskan asbâb al-wurûd-nya. Dicetak pada tahun 1329 H. ${ }^{19}$

Selain itu, juga bisa diperoleh berbagai informasi tentang asbâb al-wurûd al- hadis pada kitab-kitab Tarikh Islam (Peradaban Islam) Islam klasik. Meski demikian, tentu saja pada kitab-kitab jenis ini tidak disebutkan secara sistematis bahwa sebuah potongan informasi sejarah merupakan asbâb al-wurûd dari suatu hadis. Karena itu, para pengkaji hadis biasanya lebih memilih untuk merujuk langsung pada kitab-kitab yang secara spesifik membahas asbâb al- wurûd.

Adapun secara metodologis, cara mengetahui asbâb al-wurûd suatu hadis adalah sebagai berikut : a) Riwayat hadis Nabi (sarih \& ima'): Diperoleh melalui riwayat-riwayat yang secara integral merekam peristiwa, pertanyaan atau segala sesuatu yang melatarbelakangi ucapan atau sikap Nabi saw. baik secara tegas maupun tersirat, b) Informasi Sahabat (aqwal Shahabah): Riwayatriwayat yang disandarkan pada sahabah, mengingat mereka hidup, berinteraksi dan melihat sebagian besar peristiwa-peristiwa yang terjadi bersama Nabi saw., c) Ijtihad: Proses ijtihad pada umumnya dilakukan dengan melakukan takhrij hadis, untuk mencari segala informasi terkait dengan 19 Ibid. tema yang dikaji. Adakalanya asbâb alwurûd ditemukan dalam hadis yang berbeda periwayatnya. Proses tersebut sebenarnya masih dalam kategori tahapan mikro. Sementara untuk mencapai konteks makro terlebih ketika sebuah riwayat memang sama sekali tidak memiliki catatan kultural dalam kondisi apa ia disampaikan, maka diperlukan penelitian lebih mendalam dan lebih luas terkait dengan kondisi sosial, kultural, ekonomi, politik masyarakat Arab pada waktu itu. Sehingga ucapan atau sikap Nabi saw. yang telah wafat 15 abad yang lalu akan mudah dipahami dan dikontekstualisasikan pada masa sekarang sesuai dengan semangat zaman, kendatipun tidak harus mengurangi nilai-nilai profetik di dalamnya. ${ }^{20}$

Adapun beberapa pendekatan alternatif yang dapat digunakan sebagai alat bantu, adalah sebagaimana berikut: a) Melakukan pemahaman hadis dengan pendekatan historis, yaitu upaya memahami hadis dengan mempertimbangkan kondisi historisempiris pada saat hadis disampaikan Nabi saw., b) Pendekatan sosiologis, yaitu upaya memahami hadis dengan menyoroti dari sudut posisi manusia yang membawanya kepada perilaku itu, c) Pendekatan antropologis, yaitu upaya memahami hadis dengan memperhatikan pola-pola yang terbentuk pada tatanan nilai yang dianut dalam kehidupan masyarakat. ${ }^{21}$ d) Peter Connolly menambahkan penggunaan beberapa pendekatan psikologis untuk mengungkapkan aspek-aspek dari dalam diri manusia berkaitan dengan pengalaman dan lingkungannya. Atau dengan pendekatan feminis untuk memotret hadis berdasarkan sudut pandang yang membela perempuan atau juga pendekatan fenomenologis dan lainnya sesuai dengan orientasi dan kepentingannya. ${ }^{22}$

20 Abdul Mustaqim, Ilmu Ma'ani al-Hadis Paradigma Interkoneksi; Berbagai Teori dan Metode Memahami Hadis Nabi, (Yogyakarta: Idea Press, 2008), h. 31-32. Lihat pula al-Munawwar \& Abdul Mustaqim, Op.cit., h. 9.

${ }_{21}$ Said Agiel al-Muawwar, Ibid.

22 Lebih lanjut lihat misalnya Peter Connolly (ed.), Aneka Pendekatan Studi Agama, terj. Imam 


\section{Metodologi Memahami Hadis yang Tidak Memiliki Asbâb al-wurûd}

Di atas telah dibicarakan tentang hadis yang memilikiasbâbal-wurûd. Penting diingat, bahwa tidak semua hadis Nabi mempunyai asbâb al-wurûd-nya, karena tidak semua hadis dapat dilacak asbâb al-wurûd-nya.

Hal ini bisa terjadi karena beberapa faktor. Diantaranya, mungkin juga hilang, tercecer, tidak tercatat, atau hancur dan dihancurkan dalam bentangan sejarah panjang sejak masa Nabi dengan kita saat ini. Demikian pula, fakta sejarah menunjukkan bahwa pergolakan politik dan begitu banyak peperangan dalam sejarah Islam tentu berimplikasi secara signifikan terhadap eksistensi ilmu pengetahuan di dunia Islam klasik, termasuk di dalamnya ilmu asbâb alwurûd al-hadis.

Misalkan, penyerbuan bangsa Mongol ke Baghdad yang dipimpin oleh Jengis Khan pada tahun $656 \mathrm{H} / 1258 \mathrm{M}$, kemudian diteruskan oleh cucunya Hulagu Khan. Merupakan salah satu aksi bumi hangus yang teramat dahsyat terhadap semua bangunan peradaban Islam di Baghdad.

Sejarah berulangkali menggambarkan, sungai Tigris di Irak disesaki tumpukan buku yang digunakan para tentara Mongol itu menyeberangkan bala tentaranya. Saking banyaknya buku-buku yang dihanyutkan, air sungai besar itu berubah warna menjadi hitam karena tinta jutaan jilid buku yang luntur.

Penyerbuan itu hanya satu contoh dari sekian banyak peperangan yang perimplikasi negatif terhadap tradisi ilmiah dunia Islam masa lampau. Dengan asumsi, semua peperangan itu telah melenyapkan begitu banyak pencapaian peradaban adikuasa Dunia Islam yang pernah berjaya sekitar 9 abad.

Berdasar asumsi demikian, maka, meski ada hadis-hadis yang memang tidak mempunyai asbâbul wurûd. Besar

Khoiri (Yogyakarta: LKiS, 2009), h. 63, 105 dan 191. kemungkinan begitu banyak kitab yang membahas tentang asbâbul wurûd juga ikut musnah dalam perjalanan sejarah hingga tidak sampai ke tangan kita.

Lantas, bagaimana memahami hadis yang tidak memilikiasbâbal-wurûd? Atau, mungkin suatu hadis sebenarnya punya asbâb al-wurûd, akan tetapi tidak kita temui pada kitab-kitab yang membahas asbâb al-wurûd? Atau, asbâb al-wurûd-nya pernah dibukukan, tapi kitab itu hancur, hilang dalam perjalanan sejarah hingga tidak sampai ke masa kita.

Di sinilah barangkali dapat digunakan metode analisis pemahaman teks atau figh al-hadis, demikian istilah yang biasa dipakai para ahli hadis. Kendatipun, pembahasan tentang ini akan menguras tenaga dan pikiran tersendiri.

Pendekatan di atas bisa dipadukan dengan pendekatan historis, sosiologis, antropologis, bahkan mungkin psikososial, seperti ditulis al-Munawwar. Selain itu, metode hermeneutik yang ditawarkan oleh Abou El-Fadl dalam bukunya, God's Name: Islamic Law, Authority and Women, bisa juga dipakai. karena, Abou El Fadl menawarkan pembacaan hermeneutik dalam menelaah otoritas teks dan pengarang teks, kaitannya dengan konteks dan otoritas pembacaan teks.

\section{Implementasi Asbâbul Wurûd dalam Pemahaman Hadis Ahkam}

Implementasiasbâbal-wurûd dalam rangka megembangkan pamahaman terhadap teks suatu hadis, dapat dapat dilihat dalam kitab asbâb al-wurûd, di mana asbâb al-wurûd tersebut menyertai berbagai persoalan yang sedang dihadapi oleh Nabi, sehingga Nabi menyajikan hadis beliau baik secara verbalistik (qoulan), maupun non verbalistik (fi'lan au taqrîron).

Berikut hanya disajikan salah satu sampel, bagaimana suatu hadis tentang aqiqah ${ }^{23}$ ${ }^{23}$ Diadaptasi dari tulisan Nazhroul, Asbâb Wurûd, (Online) (Posted: February 14, 2011, http:// nazhroul.wordpress.com/Ready to Publish/Revisi Asbâb Wurûd.rtf - _ftn13 Diakses 12 Maret 2011) 
difahami melalui asbâb al-wurûd yang menyertai hadis tersebut, sehingga diperoleh pemahaman terhadap makna hadis secara beragam, sesuai dengan konteks dan upaya kontekstualisasi makna hadis di masa yang akan datang.

Sebagai upaya pemahaman aplikatif terhadap hadis menggunakan bantuan asbâb al-wurûd, tulisan ini mengambil contoh tradisi 'aqiqah, yaitu penyembelihan hewan yang dilakukan ketika lahir seorang bayi. Tradisi ini telah ada pada masyarakat Arab sebelum datangnya Islam, kemudian ada anggapan bahwa hal itu mendapat landasan teologis dari Nabi saw, (baca: disunahkan) sehingga secara berangsur-angsur setelah beliau wafat hingga sekarang tradisi tersebut tetap dilakukan oleh sebagian besar umat Islam di berbagai belahan dunia. Persoalanya adalah ketika teks keagamaan (baca: hadis) dalam hal ini dipahami secara kaku bahwa setiap lahir seorang bayi harus dilakukan 'aqiqah, bahkan tidak hanya itu, mengenai jenis atau jumlah hewan yang digunakan terkadang dimaknai sebagaimana tertulis dalam teks. Dalam hal ini tentunya akan terjadi kerumitan tersendiri dimana kondisi ekonomi masyarakat atau kondisi geografis misanya, tidak selalu memungkinkan untuk melakukan hal itu. Berdasar kasus ini, maka didemonstrasikan implementasi jasa asbâb al-wurûd sebagai salah satu instrumen dalam memahami hadis. pertama menyatakan bahwa jumlah kambing 'aqiqah untuk anak laki-laki dan perempuan tidak sama, yaitu dua ekor untuk laki-laki dan satu ekor untuk perempuan. Versi kedua menyatakan bahwa jumlah kambing 'aqiqah untuk laki-laki dan perempuan bisa di samakan dengan satu kambing. Sekilas penelusuran dalam Mausu'ah al-Hadis asSyarif, ditemukan 21 riwayat untuk versi pertama dan 2 riwayat untuk versi kedua. Dalam riwayat lain dari Ibn Abbas disebutkan bahwa Nabi melakukan 'aqiqah untuk kedua cucu beliau, masing-masing satu atau dua ekor ekor kambing gibas. ${ }^{24}$

Dalam hal ini tidak dilakukan penelitian secara mendalam mengenai kualitas matan maupun transmisi sanad masing-masing riwayat (baca: validitas) tentang 'aqiqah sebagaimana lazim digunakan sebelum melakukan penilaian ataupun pemahaman terhadap isi atau informasi dalam sebuaha hadis. Namun setidaknya secara kuantitas memang harus diakui bahwa riwayat yang menunjukkan jumlah 2 kambing untuk bayi laki-laki dan 1 kambing untuk bayi perempuan lebih banyak dari riwayatriwayat yang menunjukkan kesetaraan jumlah didalamnya. Dalam hal ini penulis hanya akan melakukan pembacaan terhadap beberapa kemungkinan alasan, latar belakang dan setting sosial masyarakat Arab melalui berbagai riwayat tentang 'aqiqah tersebut.

Tabel I

Porsi Perbandingan Kewajiban Aqiqah

2 (Laki-laki) : 1 (Perempuan)

\begin{tabular}{llll}
\hline No & Kitab & Jumlah & Nomor \\
\hline 1 & Sunan Abu Dawud & 4 & $2451,2452,2453,2459$ \\
\hline 2 & Sunan at-Tirmizi & 2 & 1433,1435 \\
\hline 3 & Sunan an-Nasa'i & 5 & $4141,4144,4145,4146,4147$ \\
\hline 4 & Sunan Ibn Majah & 2 & 3153,3154 \\
\hline 5 & Musnad Ahmad & 7 & $6426,6530,25892,26103,26106,26107,26300$ \\
\hline 6 & Sunan ad-Darimi & 1 & 1884 \\
\hline Jumlah & 21 & \\
\hline
\end{tabular}

Terdapat dua versi hadis tentang jumlah kambing yang digunakan untuk 'aqiqah. Versi
${ }^{24}$ Mausu'ah al-Hadis as-Syarif, Sunan an-Nasa'i, No. Hadis: 4148 
Qa'nabiy telah menceritakan kepada kami, Dawud ibn Qays telah menceritakan kepada kami, dari 'Umar ibn Syu'aib bahwa Rasulullah saw,.. dalam jalur lain, Muh\}ammad ibn Sulaiman alAnbariy telah menceritakan kepada kami, Ya'ni ibn 'Amr dari Dawud telah menceritakan kepada kami dari 'Amr ibn Syu'aib dari Bapaknya, aku melihatnya dari Kakeknya, berkata: "Nabi saw ditanyai tentang 'aqiqah, kemudian beliau menjawab: "Allah tidak menyukai (perbuatan durhaka) 'uquq, seakan-akan beliau tidak menyukai nama itu," kemudian bersabda: "siapa yang dikaruniai anak dan menghendaki berbuat baik (nusuk) untuk anak tersebut, maka silahkan melakukan hal itu untuk anak laki-laki dengan dua ekor kambing yang sama, dan satu ekor kambing untuk anak perempuan." 25

Telah menceritakan kepada kami Abu Bakr ibn Syaibah, telah menceritakan kepada kami 'Affan, telah menceritakan kepada kami Hummad ibn Salamah, telah memberikan kabar kepada kami 'Abdullah ibn 'Usman ibn Khusaim, dari Yusuf ibn Mahak, dari Hafsah binti 'Abdurrahman, dari 'Aisyah berkata:"Rasulullahsaw, memerintahkan kepada kami untuk menyembelih aqiqah untuk anak laki-laki dengan dua kambing dan untuk anak perempuan satu kambing." 26

Telah Menceritakan kepada kami Musaddad, telah menceritakan kepada kami Sufyan, dari 'Amr ibn Dinar, dari 'Atha', dari Habibah binti Maysarah, dari Ummi Kurz al-Ka'biyyah berkata: "aku mendengar Rasulullah saw, bersabda:" "Terhadap anak laki-laki dua kambing yang sama atau berdekatan dan terhadap anak perempuan satu kambing. "27

Melalui asbâb al-wurûd yang terintegrasi dalam teks pertama di atas, dapat dipahami bahwa Nabi saw, ditanyai tentang persoalan 'aqiqah. Terlihat dalam pembicaraan tersebut bahwa ungkapan Nabi saw, lebih merupakan sebuah himbauan atau anjuran dimana tradisi tersebut telah ada sebelumnya dan beliau tidak melarangnya. Berbeda ketika hanya melihat teks kedua yang diriwayatkan oleh 'Aisyah atau teks ketiga tanpa melihat latar belakang bagaimana beliau memerintahkan untuk melakukan 'aqiqah tanpa alasan dan rasionalitas yang jelas.

Telah menceritakan kepadaku dari Malik, dari Hisyam ibn 'Urwah bahwa bapaknya, yaitu 'Urwah ibn Zubair menyembelih 'aqiqah untuk anak laki-lakinya satu kambing dan untuk anak perempuannya satu kambing. ${ }^{28}$

Melihat informasi atau riwayat di atas barangkali memang tidak berkaitan dengan perintah Nabi saw, berkaitan dengan tradisi 'aqiqah, karena disandarkan pada perilaku sahabat (mauquf). Namun melalui teks tersebut setidaknya dapat diraba bahwa pada masa itu tradisi 'aqiqah tidak dipahami secara kaku dengan jumlah perbandingan 2 kambing untuk bayi laki-laki dan 1 kambing untuk bayi perempuan sebagaimana pemetaan sebelumnya, akan tetapi dengan jumlah yang sama untuk laki-laki dan perempuan dengan 1 kambing.

Telah menceritakan kepada kami, Abu Ma'mar

Tabel II

Porsi Perbandingan Kewajiban Aqiqah

1/2 (Laki-laki) : 1/2 (Perempuan)

\begin{tabular}{lllll}
\hline No & \multicolumn{1}{c}{ Kitab } & Jumlah & Nomor \\
\hline 1 & Sunan Abu Dawud & 1 & 2458 & \\
\hline 2 & Sunan an-Nasa'i & 1 & 4148 & \\
\hline Jumlah & 2 & & \\
\hline
\end{tabular}

25 Abu Dawud, Sunan Abu Dawud, ditahqiq Sidqi Muhammad Jamil, (Beirut: Dar al-Fikr, 1994), Juz : III. No. Hadis. 2842, h. 23.

26 Ibn Majah, Sunan al-Mustafa, diberi Hasyiyah oleh Muhammad ibn Abdul Hadi, (Beirut: Dar al-Fikr, tth.), No. Hadis. 3218, h. 280.

\footnotetext{
${ }^{27}$ Abu Dawud, Sunan Abu Dawud, No. Hadis. 2834, h. 21 .

28 Malik ibn Anas, al-Muwatta' dengan penomeran Muhammad Fu'ad Abdul Baqi, (Dar al-Kutub al-'Ilmiyyah, 1996), Juz II, No. Hadis. 7, hlm. 501.
} 
'Abdullah ibn 'Amr, telah menceritakan kepada kami Abul Waris, telah menceritakan kepada kami Ayyub, dari 'Ikrimah, dari Ibn 'Abbas bahwa Rasulullah saw, menyembelih 'aqiqah untuk Hasan dan Husain masing-masing satu kambing. ${ }^{29}$

Telah memberikan kabar kepada kami Ahmad ibn Hafs ibn 'Abdullah, berkata: telah menceritakan kepadaku Bapakku, berkata: telah menceritakan kepadaku Ibrahim, dia Ibn Tahman, dari Hajjaj ibn al-Hajjaj, dari Qatadah, dari 'Ikrimah, dari Ibn 'Abbas, berkata: Rasulullah saw, menyembelih hewan 'aqiqah untuk Hasan dan Husain ra. masing-masing dengan dua ekor kambing. ${ }^{30}$

Begitu juga dengan dua teks hadis fi'li di atas, terlepas dari kualitas transmisi sanad periwayatannya, terlihat Nabi saw, juga melakukan aqiqah dengan menyembelih kambing untuk cucunya Hasan dan Husain masing-masing satu kambing atau dalam teks kedua masing-masing dua kambing.

Melalui analisa sebagaimana sekilas diuraikan, dapat ditarik sebuah pemahaman sederhana bahwa tradisi menyembelih hewan untuk menyambut kelahiran bayi telah ada ada zaman jahiliah, sehingga disunnahkannya aqiqah termasuk dalam masalah mu'amalah yang dipengaruhi oleh budaya setempat. Di sisi lain, masyarakat Arab waktu itu masih sangat patriarkhis, dimanahegemonilaki-lakisangatkuat.Sistem nilai yang berlaku waktu itu (sebelum Islam turun) juga masih sangat minor memandang perempuan. Perbandingan 2:1 merupakan konstruk sosial yang "hanya" layak pada waktu itu. Meskipun hal ini secara tekstual mendapatkan legitimasi teologis dari Nabi saw. ${ }^{31}$

Oleh karena itu, jumlah atau jenis hewan yangdijadikanaqiqahkiranyabukan persoalan

\footnotetext{
hlm. 23 .

${ }^{29}$ Abu Dawud, Sunan Abu Dawud, No. Hadis. 2841, 4148

30 Mausu'ah al-Hadis as-Syarif, Op.cit., Hadis:

31 Abdul Mustaqim, Ilmu Ma'anil Hadis, Loc. Cit., h. 124.
}

yang harus dipahami secara kaku. Tidak salah jika pada saat lahir anak perempuan, ada kelebihan harta dan kemudian ber-aqiqah dengan dua ekor atau lebih. Atau ketika lahir anak laki-laki sementara kondisi ekonomi tidak memungkinkan untuk melaksanakan aqiqah, diperbolehkan ber-aqiqah dengan satu ekor kambing bahkan tidak ber-aqiqah sama sekali. Poin penting atau semangat yang ditekankan dalam hadis-hadis tersebut barangkali adalah ideal moral yang terkandung di dalamnya, yaitu ungkapan rasa syukur atas keselamatan bayi yang dianugerahkan oleh Allah swt.

Dengan demikian, aqiqah bukan sebuah kewajiban mengikat karena bentuknya lebih kepada himbauan. Meskipun demikian, hal ini tetap dianjurkan bagi yang mampu dengan tujuan beribadah dan bersedekah.

\section{Kesimpulan}

Pehaman terhadap suatu hadis, dalam tradisi kontemporer seperti sekarang ini diperlukan berbagai macam pendekatan maupun metodologi yang bervariasi serta keterlibatan disiplin ilmu tertentu. Penggunaan tersebut dimaksudkan karena produk hadis secara disiplin keilmuan muncul dalam kurun waktu dan konteks dan ruang waktu yang jauh dari konteks kehidupan komtemporer seperti sekarang ini.

Maka dalam tradisi ulumul hadis, salah satu instrumen pemahaman makna hadis yang sangat membantu mengembangkan makna hadis dalam konsteks kekinian adalah disiplin ilmu asbâb al-wurûd. Dengan berbagai karakter dan dimensinya, asbâb al-wurûd pada akhirnya diharapkan dapat diimplementasikan dalam rangka menggali dan mengembangkan semangat syariah (ideal normatif) yang bersifat universal, yang secara implisit tertuang dalam teks suatu hadis, sehingga nilai universal tersebut dapat diimplementasikan sesuai dengan tuntutan ruang dan waktu yang berbeda (sholihun likulli zaman wa al-makan). 


\section{DAFTAR PUSTAKA}

Abdullah, Amin, 2008, Mempertautkan Ulum Al-Diin, Al-Fikr Al-Islamiy dan Dirasat Islamiyyah: Sumbangan Keilmuan Islam untuk Peradaban Global dalam http:// aminabd. word press. com /category/ tulisan

al-Khatib, 1993, Muhammad Ajjaj, As-Sunnah Qabla al-Tadwin, Bairut: Dar al-Fikri.

al-Munawwar, Said Aqil Husein, 1998, Metode Pemahaman Hadist: Pendekatan Historis, Sosiologis dan Antropologis, Metafora

al-Munawwar, Said Agil Husin \& Abdul Mustaqim, 2001, Asbâbul Wurûd; Studi Kritis Hadis Nabi Pendekatan SosioHistoris-Kontekstual, Yogyakarta: Pustaka Pelajar.

Amamah, Adnan Muhammad, 1424 H, AtTajdid fi al-Fikr al-Islami, Saudi Arabia: Dar Ibnu Hazm.

Anas, Malik ibn, 1996, al-Muwatta' dengan penomeran Muhammad Fu'ad Abdul Baqi, Dar al-Kutub al-'Ilmiyyah, Juz II, No. Hadis. 7.

as-Salih, Subhi, 1977, Ulum al-Hadits wa Mustalahuhu, Bairut: Dar al-Ilm alMalayin.

Ash-Shidiqqy, TM. Hasbi, 1997, Sejarah dan Pengantar Ilmu Hadis, Semarang: PT. Pustaka Rizki Putra, Cet. I.

as-Suyuthi, Jalaluddin Abrdurrahman, tth., al-Luma' fi Asbâbi wurûd al-Hhadis, Beirut: Dar al-Fikr.

as-Suyuthi, Jalal ad-Din, 1984, Asbâb Wurûd al-Hadis aw al-Luma' fi Asbâb al-Hadis, ditahqiq Yahya Isma'il Ahmad, Beirut: Dar al-Kutub al-'Ilmiyyah.

as-Syafi'i, Muhammad ibn Idris, th., $A r$ Risalaah, Beirut: Dar al Fikr,

at-Thahhan, Mahmud, 1979, Taisir Musthalah
al-Hadis, Beirut : Dar al-Quran alKarim.

Connolly, Peter (ed.), 2009, Aneka Pendekatan Studi Agama terj. Imam Khoiri, Yogyakarta: LKiS.

Dawud, Abu, 1994, Sunan Abu Dawud ditahqiq Sidqi Muhammad Jamil , Beirut: Dar al-Fikr, Juz III. No. Hadis. 2842.

El-Fadl, Khaled Abou, 1997, And God Knows The Soldiers, The Authoritative and Authoritarian in Islamic Discourse, Maryland: University Press of America.

Hasyim, Ahmad Umar, tth., Qowaid Ushul alHadist, Beirut: Dar al-Fikr.

Ilyas, Yunahar dan M Mas'udi (ed.), 1996, Pengembangan Pemikiran terhadap Hadis, Yogyakarta: LPPI UMY.

Khaeruman, Badri, 2004, Otentisitas Hadis: Studi Kritis atas Kajian Hadis Kontemporer, Bandung: Rosda.

Majah, Ibn, tth., Sunan al-Mustafa, diberi Hasyiyah oleh Muhammad ibn Abdul Hadi, Beirut: Dar al-Fikr, No. Hadis. 3218.

Manzur, Ibn, 1990, Lisan al-Arab,Beirut: Dar al-Fikr, Jilid I.

Mausu'ah al-Hadis as-Syarif, tth., Sunan anNasa'i, No. Hadis: 4148

Mustaqim, Abdul, 2008, Ilmu Ma'anil Hadis Paradigma Interkoneksi; Berbagai Teori dan Metode Memahami Hadis Nabi, Yogyakarta: Idea Press.

Nazhroul, 2011, Asbâb Wurûd, Posted: February 14, Diakses 14 Februari 2011.

Warson, Ahmad, 1984, Kamus Al-Munawwir Arab-Indonesia, Yogyakarta: Unit Pengadaan Buku-buku Ilmiah Keagamaan. 